\title{
Substrate and temperature on germination and performance of Albizia niopoides Benth. seedlings
}

\author{
Dandara Yasmim Bonfim de Oliveira Silva ${ }^{1}$ Alécio Martins Pereira da Silva ${ }^{1}$ \\ Séfora Gil Gomes de Farias ${ }^{*} \odot$ Romário Bezerra e Silva ${ }^{1}$ \\ Valderez Pontes Matos $^{2}$ Leovandes Soares da Silva ${ }^{3}$
}

${ }^{1}$ Curso de Engenharia Florestal, Universidade Federal do Piauí (UFPI), Campus Professora Cinobelina Elvas (CPCE), 64900.000, Bom Jesus, PI, Brasil. E-mail: seflora@gmail.com. .Corresponding author.

${ }^{2}$ Departamento de Agronomia, Universidade Federal Rural de Pernambuco (UFRPE), Recife, PE, Brasil.

${ }^{3}$ Pós-graduação em Ciência Florestal, Universidade Federal dos Vales do Jequitinhonha e Mucuri (UFVJM), Diamantina, MG, Brasil.

\begin{abstract}
This study aimed to determine the most appropriate conditions of temperature and substrate for germination and performance of A. niopoides seedlings. The design was completely randomized in 10x7 factorial arrangement (eight constant temperatures of 5 , 10, 15, 20, $25,30,35$, and $40^{\circ} \mathrm{C}$ and two alternating temperatures of $20-30$ and $25-35^{\circ} \mathrm{C}$, and seven substrates, that are paper towel, vermiculite, sand, blotting paper, coir dust, sugarcane bagasse, and tropstrato ${ }^{\circledR}$ ) with four replicates of 25 seeds. The following variables were analyzed: (1) germination percentage; (2) germination speed index; (3) shoot length and primary root; and (4) dry weight of shoot and of root system. There was a significant interaction among the tested factors for all variables. The A. niopoides seeds germinate under a wide temperature range, with minimum and maximum limit at 10 and $40^{\circ} \mathrm{C}$ temperatures, respectively. Alternating temperatures of $20-30$ and $25-35^{\circ} \mathrm{C}$ with sand substrate are ideal conditions for germination and performance of $A$. niopoides seedlings.
\end{abstract}

Key words: forest seeds, seed analysis, vigor.

\author{
Substrato e temperatura na germinação e \\ desempenho de plântulas de Albizia niopoides
}

RESUMO: Objetivou-se com a realização deste estudo determinar as condições mais adequadas de temperatura e substrato para germinação $e$ desempenho de plântulas de Albizia niopoides. O delineamento utilizado foi o inteiramente casualizado em arranjo fatorial $10 x 7$ (oito temperaturas constantes de 5, 10, 15, 20, 25, 30, 35 e 40 ${ }^{\circ} \mathrm{C}$ e duas alternadas $20-30$ e 25-35 $\mathrm{C}$ e sete substratos: papel tolha, vermiculita, areia, papel mata borrão, pó de coco, bagaço de cana e tropstrato $\left.{ }^{\circledR}\right)$, com quatro repetições de 25 sementes. Foram analisadas as seguintes variáveis: percentagem de germinação, índice de velocidade de germinação, comprimento de parte aérea e raiz primária e massa seca da parte aérea e do sistema radicular. Houve interação significativa dos fatores testados para as todas as variáveis analisadas. As sementes de A. niopoides germinam em uma ampla faixa de temperatura, com limite mínimo e máximo nas temperaturas de 10 e $40^{\circ} \mathrm{C}$, respectivamente. As temperaturas alternadas de $20-30^{\circ} \mathrm{C}$ e $25-35^{\circ} \mathrm{C}$ com o substrato areia são condições ideais para germinação e desempenho de plântulas de A. niopoides. Palavras-chave: sementes florestais, análise de sementes, vigor.

\section{INTRODUCTION}

Germination process is regulated by many factors such as seed viability, dormancy, environmental conditions (water, light, temperature, oxygen, among others), and the absence of pathogenic organisms associated with the type of substrate (BRASIL, 2009; CARVALHO \& NAKAGAWA, 2012). On this basis, it is noted that researches are important and needed, regarding to the germination ideal conditions, especially related to native forest species, whose studies are still limited. Such information will help seed analysis for seedlings production for many purposes (GUEDES et al., 2010; SMIDERLE \& LUZ, 2010).
Substrate and temperature are two important abiotic factors affecting the germination process (MARTINS et al., 2013; OLIVEIRA et al., 2016). The substrate stands out as one of the most important factors that affect the seedling development (NOGUEIRA et al., 2012), since it is the found component to replace the soil in which the roots proliferate, and serves as support for the plant aerial part, it works supplying moisture to seeds and providing suitable conditions for germination and subsequent seedlings development(LIMAetal., 2010). The substrate type to be used should be appropriate for germination physiological requirements of each species, as well as the requirements by the Rules for Seed Analysis (RSA) (BRASIL, 2009). 
As the substrate, temperature is also seen as one of the main abiotic factors that influence germination, and may interfere in the total germination, germination speed rate, water absorption speed rate, biochemical reactions, and decisive physiological processes in the germination process (CARVALHO \& NAKAGAWA, 2012). For most tropical forest species, temperature ranging from 25 to $30^{\circ} \mathrm{C}$ is considered optimal for seed germination (BRANCALION et al., 2010) and may vary in accordance with the temperatures found in their region of origin.

Studies related to the influence of these factors have been widely developed in seed technology area. However, due to the diversity of Brazilian flora, some species have not been studied, and others have limited information, such as the Albizia niopoides Benth., a native forest species, belonging to the Fabaceae family, with multiple uses; it can be used in urban afforestation, in recovering degraded areas, in agroforestry systems, among other uses (CARVALHO, 2009).

In this context, this study aimed to determine the most appropriate conditions of temperature and substrate for germination and performance of $A$. niopoides seedlings.

\section{MATERIALS AND METHODS}

The experiment was carried out from November 2014 to February 2015, at the Forest Ecophysiology Laboratory of the Universidade Federal do Piauí, Professora Cinobelina Elvas Campus, Bom Jesus Municipality, Piauí State, Brazil ( $9^{\circ} 4^{\prime} 28^{\prime}$ ' S, $44^{\circ} 21^{\prime} 31^{\prime \prime} \mathrm{W}$, and $277 \mathrm{~m}$ asl). To obtain seeds, fruit harvest was made directly from fifteen matrix trees, previously selected and identified in areas of savanna-caatinga transition vegetation, located in forest remnants in Bom Jesus, Piauí State; and the minimum distance among trees was $100 \mathrm{~m}$. After harvesting, fruits were taken to the laboratory and the seeds were extracted and processed manually. Before installing each treatment, the seeds were subjected to pre-germination treatment of chemical scarification with immersion in sulfuric acid for a minute to break the tegumental dormancy (CARVALHO, 2009). For disinfection, seeds were immersed in 5\% sodium hypochlorite solution for five minutes, and then washed with deionized water.

Sowing was carried out among the paper towel (arranged in rolls), vermiculite of particle sizes medium ( 90 to $100 \%$ of the particles from 0.50 to $1.19 \mathrm{~mm})$, sand, coconut powder, sugarcane bagasse, tropstrato $^{\circledR}$ (pine bark, vermiculite and peat), and blotting paper substrates; these latter substrates were distributed in transparent plastic boxes (gerbox) with cover $(11 \times 11 \times 3.5 \mathrm{~cm})$. Substrates were autoclaved at $120^{\circ} \mathrm{C}$ for two hours and moistened with $0.2 \%$ nystatin solution, following the recommendations of Rules for Seed Analysis (RSA) (BRASIL, 2009). The experiment was carried out under germination chamber of Biochemical Oxygen Demand (B.O.D) type, regulated with constant temperatures of 5, 10, 15, $20,25,30,35$, and $40^{\circ} \mathrm{C}$, and alternating temperatures from $20-30$ and $25-35^{\circ} \mathrm{C}$ under continuous light. The used luminosity condition was based on information about photoperiod for this species (D.Y.B.O. SILVA \& S.G.G. FARIAS, unpublished data).

Evaluations of the number of germinated seeds were performed daily, and adopted germination criterion was hypocotyl emergence with the consequent cotyledon emergence and protophilus emergence. The analyzed variables were: (a) germination percentage, corresponding to the total of germinated normal seedlings from sowing to the end of experiment, that is, at around 15 days after sowing, except the experiment subjected to $20^{\circ} \mathrm{C}$ temperature, which stabilized the germination in about 30 days; (b) germination speed index (GSI), carried out together with the germination test; and score of normal seedlings was performed daily, at the same time, from the first count until the value becomes constant; the index was obtained by the formula proposed by MAGUIRE (1962); (c) at the end of the germination test, the primary root and aerial part of the normal seedling from each replicate were measured with a ruler graduated in centimeters, and results were expressed in $\mathrm{cm}^{\text {seedling }}{ }^{-1}$. The average length was obtained by adding the measurements of each seedling part (roots and aerial parts in each replicate, dividing them by the number of normal seedlings measures; (d) dry weight of root system and aerial part after the measurements, the seedlings had their cotyledons removed; the parts were separated with scissors and wrapped in Kraft paper bags, previously identified by the treatment type, replicate, and seedlings parts (aerial part and root); then, they were taken to air circulating oven set at $60^{\circ} \mathrm{C}$ for 24 hours to obtain the dry mass weight. After this period, seedlings of each replicate were removed from the oven and bags and then they were weighed on an analytical balance with $0.001 \mathrm{~g}$ accuracy, and the average results were expressed in mg.seedling ${ }^{-1}$.

The experimental design was completely randomized with treatments distributed in a $10 \mathrm{x} 7$ factorial arrangement $[5,10,15,20,25,30,35,40$, 
20-30, and $25-35^{\circ} \mathrm{C}$ temperature $\mathrm{x}$ seven substrates (vermiculite, sand, coconut powder, sugarcane powder, tropstrato ${ }^{\circledR}$, paper towel, and blotting paper)] with four replicates; each unit was composed by 25 seeds, totaling 100 seeds per treatment. Data were submitted to normality test (Lilliefors) and to homogeneity of variances (Cochran). Subsequently, they were subjected to analysis of variance (ANOVA); when significant effect of the treatments was found; the averages were compared by the Scott-Knott test at $5 \%$ probability. Statistical analyzes were performed with the SISVAR (DEX/UFLA) software, 5.3/19992010 version (FERREIRA, 2010).

\section{RESULTS AND DISCUSSION}

On the basis of the obtained results by the analysis of variance, it was possible to verify that there was a significant interaction $(\mathrm{P} \leq 0.01)$ between temperature and substrate for all evaluated variables.

There was no germination at 5 to $10^{\circ} \mathrm{C}$ temperature in all used substrates (Table 1). At $40^{\circ} \mathrm{C}$ temperature, it was noted small germination percentage $(17 \%)$ only on paper towel substrate; thus, it is possible to consider the temperatures of 10 and $40^{\circ} \mathrm{C}$, respectively, as the minimum and the maximum for seed germination of studying species (Table 1). This range is in agreement with MARCOS FILHO (2015), who reported that the seed germination occurs under the minimum $15^{\circ} \mathrm{C}$ temperature and the maximum from 35 to $40^{\circ} \mathrm{C}$, respectively; below and above them, the seed germination no longer occurs.

Lower temperatures can cause the decrease in the speed rate of metabolic reactions, affecting the essential processes for the germination beginning, slowing the germination speed and percentage, in addition to increase the average germination time (TAIZ \& ZEIGER, 2009; CARVALHO \& NAKAGAWA, 2012). Conversely, higher temperatures may adversely affect the germination process as a result of possible enzymatic changes, as reported by MARCOS FILHO (2015).

The higher germination percentages were obtained in the following combinations: (a) at $20^{\circ} \mathrm{C}$ in substrate paper towel, coconut powder, and tropstrato $^{\circledR}$; (b) at $25^{\circ} \mathrm{C}$, in paper towels, coconut powder, sugarcane bagasse, and tropstrato ${ }^{\circledR}$; (c) at $30^{\circ} \mathrm{C}$, in all evaluated substrates; and $(\mathrm{d})$ at $35^{\circ} \mathrm{C}$, in a paper towel, sugarcane bagasse, and tropstrato ${ }^{\circledR}$.

Table 1 - Germination (\%) and germination speed index (GSI) of Albizia niopoides Benth. seeds subjected to different temperatures and substrates.

\begin{tabular}{|c|c|c|c|c|c|c|c|c|c|c|}
\hline \multirow{2}{*}{ Substrates } & \multicolumn{10}{|c|}{ 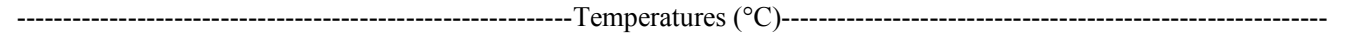 } \\
\hline & 5 & 10 & 15 & 20 & 25 & 30 & 35 & 40 & $20-30$ & $25-35$ \\
\hline \multicolumn{11}{|c|}{ 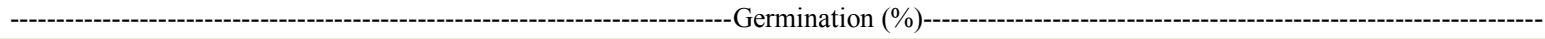 } \\
\hline BPT & $0 \mathrm{Da}$ & $0 \mathrm{Da}$ & $48 \mathrm{Bc}$ & $92 \mathrm{Aa}$ & $88 \mathrm{Aa}$ & $100 \mathrm{Aa}$ & $87 \mathrm{Aa}$ & $17 \mathrm{Ca}$ & $93 \mathrm{Aa}$ & $98 \mathrm{Aa}$ \\
\hline BV & $0 \mathrm{Ea}$ & $0 \mathrm{Ea}$ & $21 \mathrm{Dd}$ & $83 \mathrm{Ba}$ & $77 \mathrm{Bb}$ & $88 \mathrm{Aa}$ & $77 \mathrm{Ba}$ & $0 \mathrm{~Eb}$ & $43 \mathrm{Cb}$ & $92 \mathrm{Aa}$ \\
\hline BS & $0 \mathrm{Da}$ & $0 \mathrm{Da}$ & $33 \mathrm{Cd}$ & $87 \mathrm{Ba}$ & $77 \mathrm{Bb}$ & $93 \mathrm{Aa}$ & $89 \mathrm{Ba}$ & $0 \mathrm{Db}$ & $99 \mathrm{Aa}$ & $98 \mathrm{Aa}$ \\
\hline BBP & $0 \mathrm{Da}$ & $0 \mathrm{Da}$ & $49 \mathrm{Cc}$ & $60 \mathrm{Cb}$ & $77 \mathrm{Bb}$ & $87 \mathrm{Aa}$ & $60 \mathrm{Cb}$ & $0 \mathrm{Db}$ & $98 \mathrm{Aa}$ & $93 \mathrm{Aa}$ \\
\hline $\mathrm{BCP}$ & $0 \mathrm{Ca}$ & $0 \mathrm{Ca}$ & $78 \mathrm{Ba}$ & $92 \mathrm{Aa}$ & $94 \mathrm{Aa}$ & $92 \mathrm{Aa}$ & $87 \mathrm{Ba}$ & $0 \mathrm{Cb}$ & $84 \mathrm{Ba}$ & $97 \mathrm{Aa}$ \\
\hline BSB & $0 \mathrm{Ca}$ & $0 \mathrm{Ca}$ & $76 \mathrm{Ba}$ & $83 \mathrm{Ba}$ & $99 \mathrm{Aa}$ & $92 \mathrm{Aa}$ & $98 \mathrm{Aa}$ & $0 \mathrm{Cb}$ & $94 \mathrm{Aa}$ & $93 \mathrm{Aa}$ \\
\hline BT & $0 \mathrm{Da}$ & $0 \mathrm{Da}$ & $64 \mathrm{Bb}$ & $91 \mathrm{Aa}$ & $97 \mathrm{Aa}$ & $91 \mathrm{Aa}$ & $83 \mathrm{Aa}$ & $0 \mathrm{Db}$ & $87 \mathrm{Aa}$ & $51 \mathrm{Cb}$ \\
\hline \multicolumn{11}{|c|}{ } \\
\hline \multicolumn{2}{|l|}{ BPT } & $0.92 \mathrm{Da}$ & $4.75 \mathrm{Ba}$ & $5.62 \mathrm{Aa}$ & \multicolumn{2}{|c|}{$5.00 \mathrm{Ba}$} & \multicolumn{2}{|c|}{$0.40 \mathrm{Da}$} & $3.55 \mathrm{Cb}$ & $4.85 \mathrm{Bb}$ \\
\hline \multicolumn{2}{|l|}{ BV } & $0.37 \mathrm{Ea}$ & $3.50 \mathrm{Cb}$ & $5.05 \mathrm{Ab}$ & $3.25 \mathrm{Cc}$ & & & $0 \mathrm{Ea}$ & $1.55 \mathrm{Dc}$ & $4.15 \mathrm{Bc}$ \\
\hline BS & & $0.62 \mathrm{Da}$ & $4.00 \mathrm{Cb}$ & $6.07 \mathrm{Aa}$ & $3.82 \mathrm{Cb}$ & & & $0 \mathrm{Ea}$ & $4.77 \mathrm{Ba}$ & $5.55 \mathrm{Aa}$ \\
\hline BBP & & $0.92 \mathrm{Ea}$ & $2,00 \mathrm{Dc}$ & $5.10 \mathrm{Ab}$ & $4.22 \mathrm{Bb}$ & & & $0 \mathrm{Fa}$ & $3.37 \mathrm{Cb}$ & $2.90 \mathrm{Cd}$ \\
\hline BCP & & $1.07 \mathrm{Ca}$ & $2.55 \mathrm{Bc}$ & $3.95 \mathrm{Ac}$ & $2.77 \mathrm{Bc}$ & & & $0 \mathrm{Da}$ & $3.10 \mathrm{Bb}$ & $3.475 \mathrm{Ad}$ \\
\hline BSB & & $1.10 \mathrm{Da}$ & $2.35 \mathrm{Cc}$ & $4.35 \mathrm{Ac}$ & $4.15 \mathrm{Ab}$ & & & $0 \mathrm{Ea}$ & $3.85 \mathrm{Bb}$ & $3.475 \mathrm{Bd}$ \\
\hline BT & & $0.90 \mathrm{Da}$ & $2.5 \mathrm{Bc}$ & $4.15 \mathrm{Ac}$ & $2.80 \mathrm{Bc}$ & & & $0 \mathrm{Ea}$ & $3.10 \mathrm{Bb}$ & $1.85 \mathrm{Ce}$ \\
\hline
\end{tabular}

Means followed by the same letter, lower case on the column and capitalized on the line, do not differ by the Scott-Knott test at $5 \%$ probability. CV $(\%)=11.94$ and 14.53 for germination and IVG, respectively. Between paper towel (BPT); between vermiculite (BV); between sand (BS); between blotting paper (BBP); between coconut powder (BCP); between sugarcane bagasse (BSB); between Tropstrato $^{\circledR}$ (BT). 
Alternating temperatures also favor the seed germination; however, combinations of $20-30^{\circ} \mathrm{C}$ with vermiculite, and combinations of $25-35^{\circ} \mathrm{C}$ associated with tropstrato $^{\circledR}$ substrate provided germination values lower than $60 \%$ (Table 1 ).

Temperature combinations of $25,30,20$ 30 , and $25-35^{\circ} \mathrm{C}$ with the sand, vermiculite, and paper towel substrates have been indicated for carrying out the germination test of many forest species, such as Simira gardneriana M.R. Barbosa and Peixoto. (OLIVEIRA et al., 2016), Eriotheca gracilipes (K. Schum.) A. Robyns. (MELO et al., 2017) and Parkia Platycephala Benth. (SILVA et al., 2017). This result is opposite to one observed in this study for $A$. niopoides at 25 and $20-30^{\circ} \mathrm{C}$ temperatures combined with vermiculite and sand substrates associated with $25^{\circ} \mathrm{C}$ temperature.

As observed for the species under study, the temperature alternation also positively affects the seed germination of E. gracilipes (MELO et al., 2017) and $P$. platycephala (SILVA et al., 2017). BRADFORD and NONOGAKI (2007) mentioned that seeds that respond to temperature alternation conditions have enzymatic mechanisms able to operate at different temperatures; this behavior can probably be due to ecological adaptations to the environment.

With respect to germination speed rate index (GSI) (Table 1), it is observed that $25^{\circ} \mathrm{C}$ temperature, using the substrates between sand and paper towel, $35^{\circ} \mathrm{C}$, using sugarcane bagasse, and $25-35^{\circ} \mathrm{C}$ alternating temperature with the substrate between sand provided a higher germination speed for $A$. niopoides seeds.

Results from this study suggested that substrate and temperature influence seed germination. ALBUQUERQUE et al. (2009) reported that metabolic reactions, involving enzymatic activity, hydrolysis, reserve assimilation and mobilization, and cell elongation and division are already observed in the seeds, when the germination process is initiated.

Thus, in addition to physiological activities that vary according to initial seed quality, substrate properties such as structure, aeration, water retention capacity, and temperature may contribute to variations in the germination percentage values (MARTINS et al., 2013).

The optimum temperature is the one in which a higher germination percentage is obtained in a shorter time interval (MARTINS et al., 2013). In general, the optimum temperature for species multiplied by seeds ranges from 20 to $30^{\circ} \mathrm{C}$, and is related to the occurrence biome (MARCOS FILHO, 2015). Results indicate that the germination of $A$. niopoides occurs preferentially at constant temperatures of 25 and $35^{\circ} \mathrm{C}$, associated with the paper towel and sugar- cane bagasse substrates, respectively, and under the alternate temperature condition of $25-35^{\circ} \mathrm{C}$ with the sand substrate (Table 1), since such conditions provided higher germination values and in a faster way.

The largest aerial part length value of $A$. niopoides seedlings was obtained in the combination of $30^{\circ} \mathrm{C}$ with the substrate between paper towel $\left(6.20 \mathrm{~cm}\right.$. seedling $\left.^{-1}\right)$, not differing $(\mathrm{P} \leq 0.01)$ from values presented by the following interactions: (a) at $25^{\circ} \mathrm{C}$ temperature with vermiculite and sand; (b) at $35^{\circ} \mathrm{C}$ temperature with a paper towel; (c) at $20-30^{\circ} \mathrm{C}$ alternating temperature with a sand substrate; and (d) at $25-35^{\circ} \mathrm{C}$ alternating temperature with the sand and blotting paper substrates (Table 2).

The lowest values observed for the seedlings growth under lower temperatures near the minimum may be related to the effects on the soaking process under low temperatures, as reported by MARCOS FILHO (2015). This author emphasized that generally such damages are proportional to the exposure period that can extent the problem to the plant remaining cycle, and these damages are result from changes in membrane system.

Regarding the primary root length of the A. niopoides seedlings (Table 2 ), the best conditions were: (a) constant temperature of $25^{\circ} \mathrm{C}$ in tropstrato ${ }^{\circledR}$ substrate; (b) 30 and $35^{\circ} \mathrm{C}$ temperature when sugarcane bagasse is used; (c) $20-30^{\circ} \mathrm{C}$ temperature in the sand; and (d) $25-35^{\circ} \mathrm{C}$ temperature associated with paper towel.

SILVA et al. (2017) working with the $P$. platycephala species at different temperatures, reached the consensus that lower temperatures adversely affected the seedling growth; similar behavior was observed for the species under study, with a minimum limit at $15^{\circ} \mathrm{C}$ and maximum at $40^{\circ} \mathrm{C}$.

Evaluating the dry weight of the aerial part of $A$. niopoides seedlings (Table 2), it was reported that the most vigorous seedlings were obtained at $25^{\circ} \mathrm{C}$, regardless of the used substrate. In alternating temperatures, the best combinations were: (a) $20-30^{\circ} \mathrm{C}$ in the paper towels, sand, and sugarcane bagasse; and (b) $25-35^{\circ} \mathrm{C}$ in the sand and coconut powder. At 15 to $30^{\circ} \mathrm{C}$ temperature range, there was no difference $(\mathrm{P} \leq 0.01)$ for the substrate between paper towel substrates.

As for this study, $25^{\circ} \mathrm{C}$ temperature significantly favored the dry biomass of aerial parts of young plants of Copaifera langsdorffii (Desf) (NASCIMENTO et al., 2014). These authors also mentioned that this response may be related to the proper temperature for achieving the physiological processes and biochemical reactions, essential to plant growth. 


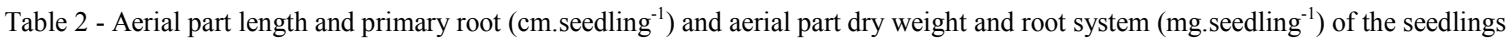
from Albizia niopoides Benth. seeds, subjected to different temperatures and substrates.

\begin{tabular}{|c|c|c|c|c|c|c|c|c|}
\hline \multirow{2}{*}{ Substrates } & \multicolumn{8}{|c|}{ - } \\
\hline & 15 & 20 & 25 & 30 & 35 & 40 & $20-30$ & $25-35$ \\
\hline & \multicolumn{8}{|c|}{ - } \\
\hline BPT & $2.30 \mathrm{Cb}$ & $1.80 \mathrm{Dd}$ & $5.17 \mathrm{Bb}$ & $6.20 \mathrm{Aa}$ & $6.07 \mathrm{Aa}$ & $2,65 \mathrm{Ca}$ & $4.70 \mathrm{Bb}$ & $4.85 \mathrm{Ba}$ \\
\hline BV & $1.47 \mathrm{Dc}$ & $3.25 \mathrm{Cb}$ & $5.45 \mathrm{Aa}$ & $5.25 \mathrm{Ab}$ & $4.57 \mathrm{Bc}$ & $0 \mathrm{~Eb}$ & $3.37 \mathrm{Cd}$ & $4.92 \mathrm{Ba}$ \\
\hline BS & $1.55 \mathrm{Cc}$ & $2.87 \mathrm{Bc}$ & $5.55 \mathrm{Aa}$ & $5.45 \mathrm{Ab}$ & $5.35 \mathrm{Ab}$ & $0 \mathrm{Db}$ & $5.12 \mathrm{Aa}$ & $5.15 \mathrm{Aa}$ \\
\hline BBP & $1.85 \mathrm{Cc}$ & $2.30 \mathrm{Cd}$ & $4.925 \mathrm{Ab}$ & $4.35 \mathrm{Ac}$ & $3.82 \mathrm{Bd}$ & $0 \mathrm{Db}$ & $4.55 \mathrm{Ab}$ & $4.47 \mathrm{Aa}$ \\
\hline BCP & $3.10 \mathrm{Da}$ & $3.72 \mathrm{Cb}$ & $4.85 \mathrm{Ab}$ & $5.25 \mathrm{Ab}$ & $4.72 \mathrm{Ac}$ & $0 \mathrm{~Eb}$ & $4.22 \mathrm{Bc}$ & $4.50 \mathrm{Ba}$ \\
\hline BSB & $3.00 \mathrm{Da}$ & $4.22 \mathrm{Ca}$ & $5.07 \mathrm{Bb}$ & $5.67 \mathrm{Ab}$ & $4.95 \mathrm{Bc}$ & $0 \mathrm{~Eb}$ & $5.15 \mathrm{Ba}$ & $4.87 \mathrm{Ba}$ \\
\hline BT & $2.55 \mathrm{Db}$ & $3.37 \mathrm{Cb}$ & $4.90 \mathrm{Ab}$ & $4.52 \mathrm{Ac}$ & $4.10 \mathrm{Bd}$ & $0 \mathrm{~Eb}$ & $3.87 \mathrm{Bc}$ & $3.55 \mathrm{Cb}$ \\
\hline \multicolumn{9}{|c|}{ (cm.seedling ${ }^{-1}$ )- } \\
\hline BPT & $1.62 \mathrm{Ea}$ & $2.65 \mathrm{Db}$ & $5.17 \mathrm{Ba}$ & $5.12 \mathrm{Bb}$ & $4.05 \mathrm{Cb}$ & $1.45 \mathrm{Ea}$ & $1.62 \mathrm{Ed}$ & $6.17 \mathrm{Aa}$ \\
\hline BV & $0.80 \mathrm{Da}$ & $1.72 \mathrm{Cc}$ & $3.27 \mathrm{Bb}$ & $3.05 \mathrm{Bd}$ & $3.15 \mathrm{Bc}$ & $0 \mathrm{~Eb}$ & $1.57 \mathrm{Cd}$ & $4.42 \mathrm{Ac}$ \\
\hline BS & $1.52 \mathrm{Da}$ & $2.82 \mathrm{Cb}$ & $3.75 \mathrm{Bb}$ & $4.22 \mathrm{Bc}$ & $3.70 \mathrm{Bc}$ & $0 \mathrm{~Eb}$ & $5.02 \mathrm{Aa}$ & $5.12 \mathrm{Ab}$ \\
\hline BBP & $1.12 \mathrm{Ca}$ & $1.02 \mathrm{Cc}$ & $3.62 \mathrm{Ab}$ & $2.40 \mathrm{Bd}$ & $2.07 \mathrm{Bd}$ & $0 \mathrm{Db}$ & $2.70 \mathrm{Bc}$ & $3.32 \mathrm{Ad}$ \\
\hline BCP & $1.55 \mathrm{Da}$ & $2.60 \mathrm{Cb}$ & $4.32 \mathrm{Ab}$ & $5.02 \mathrm{Ab}$ & $4.90 \mathrm{Ab}$ & $0 \mathrm{~Eb}$ & $3.17 \mathrm{Bb}$ & $4.85 \mathrm{Ab}$ \\
\hline BSB & $1.25 \mathrm{Ea}$ & $2.50 \mathrm{Db}$ & $3.75 \mathrm{Cb}$ & $5.80 \mathrm{Aa}$ & $5.87 \mathrm{Aa}$ & $0 \mathrm{Fb}$ & $5.10 \mathrm{Ba}$ & $4.92 \mathrm{Bb}$ \\
\hline BT & $1.37 \mathrm{Da}$ & $3.62 \mathrm{Ca}$ & $5.37 \mathrm{Aa}$ & $4.22 \mathrm{Cc}$ & $4.50 \mathrm{Bb}$ & $0 \mathrm{~Eb}$ & $3.60 \mathrm{Cb}$ & $3.70 \mathrm{Cd}$ \\
\hline \multicolumn{9}{|c|}{ 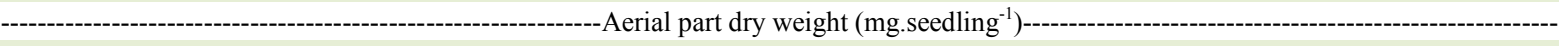 } \\
\hline BPT & $13.77 \mathrm{Aa}$ & $15.80 \mathrm{Aa}$ & $15.00 \mathrm{Aa}$ & $14.25 \mathrm{Aa}$ & $10.50 \mathrm{Bb}$ & $2,75 \mathrm{Ca}$ & $16.10 \mathrm{Aa}$ & $9.85 \mathrm{Bb}$ \\
\hline BV & $10.12 \mathrm{Cb}$ & $15.10 \mathrm{Aa}$ & $16.30 \mathrm{Aa}$ & $14.37 \mathrm{Aa}$ & $8.50 \mathrm{Cb}$ & $0 \mathrm{Db}$ & $12.02 \mathrm{Bb}$ & $12.12 \mathrm{Ba}$ \\
\hline BS & $6.17 \mathrm{Cc}$ & $14.97 \mathrm{Aa}$ & $15.72 \mathrm{Aa}$ & $14.42 \mathrm{Aa}$ & $9.60 \mathrm{Bb}$ & $0 \mathrm{Db}$ & $13.90 \mathrm{Aa}$ & $13.10 \mathrm{Aa}$ \\
\hline BBP & $10.77 \mathrm{Bb}$ & $15.07 \mathrm{Aa}$ & $15.57 \mathrm{Aa}$ & $14.57 \mathrm{Aa}$ & $9.80 \mathrm{Bb}$ & $0 \mathrm{Cb}$ & $12.50 \mathrm{Bb}$ & $11.02 \mathrm{Ba}$ \\
\hline BCP & $7.65 \mathrm{Cc}$ & $9.72 \mathrm{Bb}$ & $14.07 \mathrm{Aa}$ & $14.52 \mathrm{Aa}$ & $13.60 \mathrm{Aa}$ & $0 \mathrm{Db}$ & $12.52 \mathrm{Ab}$ & $12.2 \mathrm{Aa}$ \\
\hline BSB & $7.77 \mathrm{Cc}$ & $11.62 \mathrm{Bb}$ & $14.12 \mathrm{Aa}$ & $12.07 \mathrm{Ba}$ & $13.47 \mathrm{Aa}$ & $0 \mathrm{Db}$ & $14.40 \mathrm{Aa}$ & $12.15 \mathrm{Ba}$ \\
\hline BT & $7.47 \mathrm{Cc}$ & $10.55 \mathrm{Bb}$ & $14.10 \mathrm{Aa}$ & 14.17 Aa & $12.30 \mathrm{Aa}$ & $0 \mathrm{Db}$ & $13.27 \mathrm{Ab}$ & $8.85 \mathrm{Cb}$ \\
\hline \multicolumn{9}{|c|}{ } \\
\hline BPT & $1.24 \mathrm{Cb}$ & $2.42 \mathrm{Bb}$ & $2.74 \mathrm{Ba}$ & $2.21 \mathrm{Bb}$ & $1.91 \mathrm{Bb}$ & $0.37 \mathrm{Ca}$ & $2.12 \mathrm{Bb}$ & $3.90 \mathrm{Aa}$ \\
\hline BV & $1.68 \mathrm{Cb}$ & $3.40 \mathrm{Aa}$ & $2.20 \mathrm{Ca}$ & $2.64 \mathrm{Ba}$ & $2.18 \mathrm{Cb}$ & $0 \mathrm{Da}$ & $3.78 \mathrm{Aa}$ & $3.86 \mathrm{Aa}$ \\
\hline BS & $1.65 \mathrm{Bb}$ & $2.07 \mathrm{Bb}$ & $2.23 \mathrm{Ba}$ & $2.18 \mathrm{Bb}$ & $2.23 \mathrm{Bb}$ & $0 \mathrm{Ca}$ & $3.63 \mathrm{Aa}$ & $3.60 \mathrm{Aa}$ \\
\hline BBP & $1.26 \mathrm{Bb}$ & $1.175 \mathrm{Bc}$ & $2.32 \mathrm{Aa}$ & $1.55 \mathrm{Bb}$ & $1.52 \mathrm{Bb}$ & $0 \mathrm{Ca}$ & $3.04 \mathrm{Ab}$ & $2.66 \mathrm{Ab}$ \\
\hline $\mathrm{BCP}$ & $2.09 \mathrm{Bb}$ & $2.14 \mathrm{Bb}$ & $2.95 \mathrm{Aa}$ & $3.36 \mathrm{Aa}$ & $3.54 \mathrm{Aa}$ & $0 \mathrm{Ca}$ & $3.00 \mathrm{Ab}$ & $3.15 \mathrm{Ab}$ \\
\hline BSB & $3.80 \mathrm{Aa}$ & $2.35 \mathrm{Ab}$ & $3.20 \mathrm{Aa}$ & $3.07 \mathrm{Aa}$ & $3.20 \mathrm{Aa}$ & $0 \mathrm{Ba}$ & $3.52 \mathrm{Aa}$ & $2.95 \mathrm{Ab}$ \\
\hline $\mathrm{BT}$ & $1.99 \mathrm{Ab}$ & $2.42 \mathrm{Ab}$ & $3.02 \mathrm{Aa}$ & $3.00 \mathrm{Aa}$ & $3.20 \mathrm{Aa}$ & $0 \mathrm{Ba}$ & $2.91 \mathrm{Ab}$ & $2.68 \mathrm{Ab}$ \\
\hline
\end{tabular}

Means followed by the same letter, lower case on the column and capitalized on the line, do not differ by the Scott-Knott test at $5 \%$ probability. $\mathrm{CV}(\%)=10.36 ; 15.69 ; 12.93$; and 28.40 , following the order of the variables presented in the table. Between paper towel (BPT); between vermiculite (BV); between sand (BS); between blotting paper (BBP); between coconut powder (BCP); between sugarcane bagasse (BSB); between Tropstrato ${ }^{\circledR}(\mathrm{BT})$.

BRANCALION et al. (2010) emphasized that the species present variable behavior in relation to temperature; although, the range of $25^{\circ} \mathrm{C}$ is considered the most suitable temperature for most species of Cerrado (Savanna) biome. The $25^{\circ} \mathrm{C}$ constant temperature was favorable to increase the dry weight of Dalbergia nigra (Vell.) Fr. All. seedlings in substrates among sand, vermiculite, and paper towel (GUEDES et al., 2011).

Table 2 shows values of dry weight of $A$. niopoides root system. When $25-35^{\circ} \mathrm{C}$ alternating temperature was combined with the paper towel substrate, there was a higher average of seedling dry weight (3.9mg.seedling ${ }^{-1}$ ), while, at $15^{\circ} \mathrm{C}$ temperature in the same substrate, the lowest values for the root dry weight were obtained. This result may be related to the primary root length, because values were lower, when using the same temperature of the primary root length. Results obtained by this study suggested a great variation in the maximum expression of seed physiological potential in relation to the conditions of tested substrates and temperatures. According to SOUZA et al. (2007), this fact is common in 
such studies under laboratory conditions, making it necessary to define optimal conditions for germination and vigor of each forest species, confirming the importance of this study.

The used substrates influenced significantly the germination and performance of $A$. niopoides seedlings, with a positive emphasis on sand, sugarcane bagasse, tropstrato ${ }^{\circledR}$, and paper towel substrates. The different observed responses for the tested substrates may be due to water retention capacity, intrinsic properties that regulate the seed water flow, amount of light that the substrate allows to reach the seed, among others.

In other seeds of forest species, such as $S$. gardneriana (OLIVEIRA et al., 2016) and P.platycephala (SILVA et al., 2017), the sand and paper towel substrates were recommended for the germination test because they provided better results, as well as for E. gracilipes using the paper towel substrate (MELO et al., 2017).

Under an economic perspective, sand is a source of low cost and easy availability. Conversely, sugarcane bagasse can also be a viable and ecologically correct alternative, especially in regions where this material exists in great availability and easy acquisition.

\section{CONCLUSION}

The A. niopoides seeds germinate under a wide temperature range, with minimum and maximum limit at 10 and $40^{\circ} \mathrm{C}$ temperatures, respectively. Alternating temperatures of $20-30$ and $25-35^{\circ} \mathrm{C}$ with sand substrate are ideal conditions for germination and performance of $A$. niopoides seedlings.

\section{ACKNOWLEDGEMENTS}

The authors are grateful to the Universidade Federal do Piauí/Voluntary Scientific Initiation Program (2014/2015), the members of the Group research "Technology, production and physiology of seeds and seedlings of forest species" for their support in conducting the study and the Fundação de Amparo a Pesquisa do Estado do Piauí (FAPEPI) for financial support in publishing.

\section{REFERENCES}

ALBUQUERQUE, K. S. et al. Physiological and biochemical alterations during germination of sucupira-preta (Bowdichia virgilioides Kunth.) seeds. Revista Brasileira de Sementes, v. 31, n. 1, p. 12-19, 2009. Available from: $<$ http://www.scielo.br/scielo.php?pid=S0101$31222009000100028 \&$ script $=$ sci abstract\&tlng $=\mathrm{pt}>$. Accessed: 1 , May 2017. doi: <http://dx.doi.org/10.1590/S0101-31222009000100028>.

BRADFORD, K. J.; NONOGAKI, H. Seed development, dormancy and germination. Oxford: Blackwell Publishing, 2007. 392p.

BRANCALION, P. H. S. et al. Optimal temperature for seed germination of brazilian tree species. Revista Brasileira de
Sementes, v.32, n. 4, p.15- 21, 2010. Available from: <http://www. scielo.br/pdf/rbs/v32n4/02.pdf>. Accessed: 14 Sept. 2016. doi: 10.1590/S0101-31222010000400002.

BRASIL. Ministério da Agricultura, Pecuária e Abastecimento. Regras para análise de sementes. Ministério da Agricultura, Pecuária e Abastecimento. Secretaria de Defesa Agropecuária. Brasília: MAPA/ACS, 2009. 395p.

CARVAlHO, N. M.; NAKAGAWA, J. Sementes: ciência, tecnologia e produção. 5.ed. Jaboticabal: FUNEP, 2012.

CARVALHO, P. E. R. Espécies arbóreas brasileiras. Brasília, DF: Embrapa Informação Tecnológica; Colombo: Embrapa Florestas, 2009. 8p. (Comunicado Técnico, 226).

FERREIRA, D. F. Programa computacional Sisvar - UFLA, versão $5.3,2010$.

GUEDES, R. S. et al. Temperatures and substrates for germination and vigor test of Amburana cearensis (Allemão) A.C. Smith seeds. Revista Árvore, v.34, n.1, p.57-64, 2010. Available from: <http:// www.scielo.br/pdf/rarv/v34n1/v34n1a07>. Accessed: 14 Sept. 2016. doi: 10.1590/S0100-67622010000100007.

GUEDES, R. S. et al. Germination of Dalbergia nigra (Vell.) Fr. All. seeds. Acta Scientiarum. Biological Sciences, v.33, n.4, p.445-450, 2011. Available from: <http://eduem.uem.br/ojs/index. php/ActaSciBiolSci/article/view/5834/5834>. Accessed: 14 Sept. 2016. doi: 10.4025/actascibiolsci.v33i4.5834.

LIMA, J. F. et al. Evaluation of different substrates in the physiological quality of caroá melonm [Sicana odorifera (Vell.) Naudim] seeds. Revista Brasileira de Plantas Medicinais, v.12, n.2, p.163-167, 2010. Available from: <http://www.sbpmed.org.br/ download/issn_10_2/v12_2_163_167.pdf $>$. Accessed : 14 Sept. 2016. doi: $10 . \overline{1590 / \mathrm{S} 1516-05722010000200007 .}$

MAGUIRE, J. D. Speed of germination-aid in selection and evaluation for seedling emergence and vigor. Crop Science, v. 2, n. 1, p. 176-177, 1962. Available from: <https://dl.sciencesocieties. org/publications/cs/abstracts/2/2/CS0020020176/>. Accessed: 15 Sept. 2016. doi: 10.2135/cropsci1962.0011183X000200020033x.

MARCOS-FILHO, J. Fisiologia de sementes de plantas cultivadas. Associação Brasileira de Tecnologia de Sementes ABRATES, Londrina, PR, 2015. 659p.

MARTINS, C. C. et al. Effects of substratum, temperature, and treatments to overcome dormancy on the germination of Fimbristylis dichotoma seeds. Revista de Ciências Agrárias, v. 56, p. 44-48, 2013. Suplemento. Available from: $<$ http://doi.editoracubo. com. br/10.4322/rca.2013.079>. Accessed: 1 May 2017. doi: <http:// dx.doi.org/10.4322/rca.2013.079>.

MELO, P. A. F. R. et al. Substrates and temperatures in the germination of Eriotheca gracilipes seeds. Revista Ciência Agronômica, v. 48, n. 2, p. 303-309, 2017. Available from: <http://www.scielo.br/scielo. php?script $=$ sci_arttext\&pid=S180666902017000200303\&lng=en\&nr m=iso $>$. Accessed: 1 May 2017. doi: 10.5935/1806-6690.20170035.

NASCIMENTO, M. E. et al. Morphlogical evaluation of Copaifera langsdorffii Desf. saplings grown in different temperatures. Revista Brasileira de plantas medicinais, v.16, n.4, p.931-937, 2014. Available from: <http://www.scielo.br/pdf/rbpm/v16n4/ a19v16n4. pdf>. Accessed: 14 Sept. 2016. doi: 10.1590/1983-084X/11_176. 
NOGUEIRA, N. W. et al. Emergence and initial development of Mimosa caesalpiniifolia Benth. seedlings for different substrates. RevistaAgro@mbiente On-line, v.6, n.1, p.17-24, 2012. Available from: <http://revista.ufrr.br/agroambiente/article/view/695/ 685>. Accessed: 14 Sept. 2016. doi: <http://dx.doi.org/10.18227/19828470ragro. v6i1>.695.

OLIVEIRA, F. N. et al. Temperature and substrate on the germination of seeds of Simira gardneriana M.R. Barbosa \& Peixoto. Revista Ciência Agronômica, v. 47, n. 4, p. 658-666, 2016. Available from: <http://www.ccarevista.ufc.br/seer/index. php/ ccarevista/article/view/4314 >. Accessed: 1 May 2017. doi: 10.5935/1806-6690.20160079.

SILVA, R. B. et al. Germination and seedling vigour in Parkia platycephala Benth. in different substrates and temperatures. Revista Ciência Agronômica, v. 48, n. 1, p. 142-150, 2017. Avaliable from:
$<$ http://www.scielo.br/pdf/rca/v48n1/1806-6690-rca-48-01-0142. pdf $>$. Accessed: 1 May 2017. doi: 10.5935/1806-6690.20170016.

SOUZA, E. B. et al. Germination of Adenanthera pavonina L. seeds as a function of different temperatures and substrates. Revista Árvore, v. 31, n. 3, p. 437-443, 2007. Avaliable from: <http://www.scielo.br/ scielo.php?script $=$ sci_arttext\&pid $=\mathrm{S} 0100-67622007000300009>$. Acessed: 1 May 2017. doi: 10.1590/S0100-67622007000300009.

SMIDERLE, O. J.; LUZ, F. J. F. Overcoming dormancy of patade-vaca (Bauhinia angulata Vell) seeds. Revista Agro@ambiente On line, v. 4, n. 2, p. 80-85, 2010. Available from: <http://revista. ufrr.br/agroambiente/article/view/374/294>. Accessed: 15 Sept. 2016. doi: 10.18227/1982-8470ragro.v4i2.374.

TAIZ, L., ZEIGER, E. 2009. Fisiologia vegetal. 4.ed. Artmed, Porto Alegre, Brasil. 719 p. 